\title{
IDENTIFIKASI FLAVANOID PADA EKSTRAK DAUN MELINJO (GENATUM GENANOM L.)
}

\author{
Putriana Rachmawati \\ Sekolah Tinggi Ilmu Kesehatan Harapan Bangsa Purwokerto
}

\begin{abstract}
Abstrak
Tanaman melinjo merupakan komoditas pangan yang melimpah di Indonesia dan memiliki banyak manfaat bagi pengkonsumsinya mulai dari daun muda, bunga, biji, hingga kulitnya. Menurut Voondan Kueh (1999) semua makanan yang berasal dari tanaman melinjo memiliki komponen gizi yang tinggi, seperti karbohidrat sebesar 6,60\%, protein sebesar 4,20\%, kalsium sebesar 94,00 mg, vitamin C1, $500 \mathrm{mg}$ dan lainnya. Metode penelitian ini yaitu analisis spektofotometri Uv-Vis yang dilakukan pada sampel daun melinjo dengan pengukuran absorbansi standar flavonoid kuersetin pada panjang gelombang $424 \mathrm{~nm}$. Hasil penelitian menunjukan bahwa kandungan flavonoid daun melinjo (Gnetum gnemon L) pada desa Rempoah lebih tinggi dibandingkan dengan kandungan flavonoid daun melinjo (Gnetum gnemon L) di Desa Dukuh Waluh. Desa Rempoah memiliki tekstur tanah padat, yang mengakibatkan akar dengan mudah menyerap air dari dalam tanah karena butiran partikel tanah dapat menahan laju air sehingga perakaran tanaman mudah menyerap air, akibatnya pertumbuhan tanaman juga semakin baik. Ditunjukan dengan kandungan pigmen flavonoid yang lebih baik dari Desa Dukuh Waluh. Sedangkan pada daerah Dukuh Waluh struktur tanahnya berpasir dan berkerikil mengakibatkan daya ikat airnya sangat lemah karena partikel-partikel tanah terlalu renggang akibatnya perakaran tanah kurang mendapat suplai air sehingga pertumbuhan tanaman juga tidak baik, sehingga kandungan flavonoid juga lebih sedikit. Tanah yang padat menyebabkan akar dengan mudah menyarap garam-garam mineral dan mengakibatkan kandungan metabolit sekunder meningkat.
\end{abstract}

Kata kunci : mlinjo, penetapan, flavanoid

\begin{abstract}
Melinjo plants are an abundant food commodity in Indonesia and have many benefits for consumption ranging from young leaves, flowers, seeds, to the skin. According to Voondan Kueh (1999) all foods derived from melinjo plants have a high nutritional component, such as carbohydrates at $6.60 \%$, protein at $4.20 \%$, calcium at $94.00 \mathrm{mg}$, vitamins $\mathrm{Cl}, 500 \mathrm{mg}$ and others. The method of this research is Uv-Vis spectrophotometry analysis performed on melinjo leaf samples by measuring the standard absorbance of quercetin flavonoids at a wavelength of $424 \mathrm{~nm}$. The results showed that the content of melinjo leaf flavonoids (Gnetum gnemon L) in Rempoah village was higher than the content of melinjo leaf flavonoids (Gnetum gnemon L) in Dukuh Waluh Village. Rempoah village has a solid soil texture, which causes the roots to easily absorb water from the soil because the particles of soil can hold back the rate of water so that the roots of plants easily absorb water, as a result the plant growth is also getting better. Shown with the content of flavonoid pigments that are better than Dukuh Waluh Village. Whereas in the Dukuh Waluh area the sandy and gravel soil structure results in very weak water binding capacity because the soil particles are too tenuous as a result of lack of water supply so that plant growth is also not good, so there is less flavonoid content. Solid soil causes the roots to easily handle mineral salts and results in increased secondary metabolite content.
\end{abstract}

Keywords: mlinjo, determination, flavanoids

Vwa Medika | EDISI KHUSUS/SERI 1/ NOVEMBER/2017 


\section{PENDAHULUAN}

Melinjo (Gnetum gnemonL.) merupakan salah satu jenis tanaman berbiji terbuka (Gymnospermae), dimana dagingnya terbungkus oleh kulit luar. Tanaman melinjo merupakan komoditas pangan yang melimpah di Indonesia dan memiliki banyak manfaat bagi pengkonsumsinya mulai dari daun muda, bunga, biji, hingga kulitnya. Menurut Voondan Kueh (1999) semua makanan yang berasal dari tanaman melinjo memiliki komponen gizi yang tinggi, seperti karbohidrat sebesar $6,60 \%$, protein sebesar 4,20\%, kalsium sebesar 94,00 mg, vitamin C1 , $500 \mathrm{mg}$ dan lainnya. Bagian tanaman yang sering dimanfaatkan adalah biji melinjo, selain dimakan dengan cara di rebus dapat juga diolah menjadi emping. Kulit biji melinjo dapat diaplikasikan untuk bahan baku pembuatan keripik kulit melinjo sedangkan daun melinjo umumnya dimasak menjadi sayuran atau lauk-pauk.

Menurut Hanan dan Sutrisno (2000) melinjo merupakan tanaman yang mengandung antioksidan tinggi, sehingga dapat menghambat radikal bebas dan dapat berfungsi sebagai antiaging. Aktivitas antioksidan yang tinggi pada suatu bahan pangan dipengaruhi oleh senyawa yang ada didalamnya (Septiani et al., 2012). Menurut Permadi (2006) didalam Dewi (2011) daun melinjo (Gnetum gnemonL.) serta buahnya mengandung tanin, saponin, dan flavonoid. Menurut Dewi (2011) melinjo memiliki aktivitas antioksidan tertinggi pada bagian daun yaitu sebanyak 5,97\% yang diperoleh dengan metode ekstraksi pemanasan (perebusan) pada suhu $60^{\circ} \mathrm{C}$ menggunakan pelarut akuades. Sedangkan pada bagian kulit buah memiliki aktivitas antioksidan terendah yaitu 2,47\% dengan perlakuan yang sama.

Pada umumnya antioksidan terdiri dari dua jenis yaitu antioksidan alami dan antioksidan sintetik. Namun saat ini penggunaan antioksidan sintetik sudah dibatasi, hal ini didasari bahwa antioksidan sintetik yaitu BHT (Butylated HydroxyToluena) ternyata dapat meracuni binatang dan bersifat karsinogen. Oleh karena itu saat ini industri makanan dan obat-obatan banyak yang beralih mengembangkan dan mencari sumber antioksidan alami dan melinjo merupakan 
salah satu tanaman yang mengandung antioksidan alami (Takashi dan Takayuni, 1997).

\section{METODOLOGI}

1. Pengambilan Sampel Penelitian

Sampel yang digunakan adalah sampel daun melinjo (Gnetum gnemon L) pada desa Dukuh Waluh dan Rempoah. Daun melinjo yang diambil pada kedua tempat berbeda disimpan didalam plastik yang diberi label. Kemudian sampel daun dibawa ke laboratorium untuk dilakukan ekstraksi dan diuji kandungannya.

\section{Preparasi Sampel}

Sampel yang telah di ambil dari lokasi penelitian di keluarkan dan dicuci sampai bersih. Kemudian dikeringkan pada oven dengan suhu $46^{0} \mathrm{C}$ selama 3 jam untuk menghilangkan kadar air dalam melinjo hingga didapat berat konstan. Selanjutnya daun melinjo dihaluskan dengan menggunakan blender dan dilanjutkan dengan pengayakan menggunakan kertas saring. Pengayakan dilakukan untuk mengecilkan ukuran serbuk dan mempermudah pelepasan zat aktif pada saat proses ekstraksi.

\section{Ekstraksi Maserasi}

Ekstrak cair melinjo dilakukan pengenceran 10x diambil menggunakan pipet dan ditetesi pada tabung reaksi dan diamati perubahan warnanya sebelum dan sesudah ditetesi peraksi. Pereaksi yang digunakan adalah $\mathrm{NaOH}$.

Pelarut yang digunakan dalam penelitian ini adalah metanol yang disesuaikan dengan kepolaran senyawa. Setelah sampel menjadi serbuk kemudian ditakar dengan metanol dengan perbandingan 1:5. Kemudian ditutup dan dibiarkan selama 1 malam. Selama 1 malam akan menghasilkan ekstrak kental. Larutan yang didapat kemudian disaring dengan menggunakan kertas penyaring. Sampel di uapkan dengan menggunakan rotary evaporator dan mendapat ekstrak cair yang kemudian di water bath pada suhu $40^{\circ} \mathrm{C}$ selama 12 jam.

4. Identifikasi Flavonoid

Identifikasi dilakukan pengulangan sebanyak tiga kali. Ekstrak cair melinjo yang telah dilakukan 
pengenceran 10x diambil menggunakan pipet dan ditetesi pada tabung reaksi dan diamati perubahan warnanya sebelum dan sesudah ditetesi peraksi. Pereaksi yang digunakan adalah $\mathrm{NaOH}$.

\section{HASIL DAN PEMBAHASAN}

Adanya flavonoid ditandai dengan berubahnya warna pada sampel yang sudah diberi pelarut $\mathrm{NaOH}$ (Basa kuat). Sebelumnya sampel berwarna hijau, tetapi setelah diberi pelarut $\mathrm{NaOH}$ kemudian dikocok maka warna yang terbentuk pada sampel adalah warna kuning (Harborne, 1987)

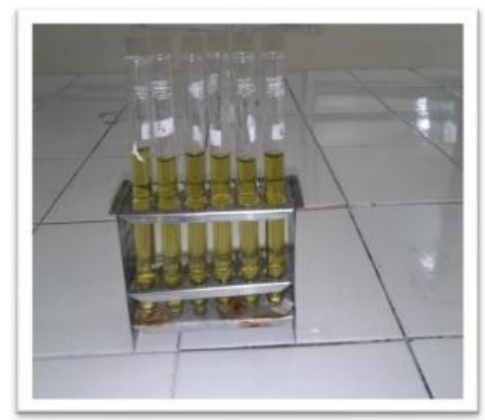

Gambar 1. Sampel sebelum diberi $\mathrm{NaOH}$

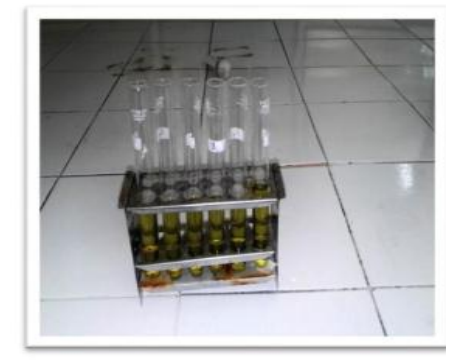

Gambar 2. Sampel sesudah diberi $\mathrm{NaOH}$ Hasil penelitian menunjukan bahwa kandungan flavonoid daun melinjo (Gnetum gnemon L) pada desa Rempoah lebih tinggi dibandingkan dengan kandungan flavonoid daun melinjo (Gnetum gnemon L) di Desa Dukuh Waluh. Desa Rempoah memiliki tekstur tanah padat, yang mengakibatkan akar dengan mudah menyerap air dari dalam tanah karena butiran partikel tanah dapat menahan laju air sehingga perakarantanaman mudah menyerap air, akibatnya pertumbuhan tanaman juga semakin baik. Ditunjukan dengan kandungan pigmen akibatnya perakaran tanah kurang mendapat suplai air sehingga pertumbuhan tanaman juga tidak baik, sehingga kandungan flavonoid juga lebih sedikit. Tanah yang padat menyebabkan akar dengan mudah menyarap garamgaram mineral dan mengakibatkan 
kandungan metabolit sekunder meningkat

(Pinem, 2007).

\section{KESIMPULAN}

Hasil penlitian menunjukkan adanya flavonoid ditandai dengan berubahnya warna pada sampel yang sudah diberi pelarut $\mathrm{NaOH}$ (Basa kuat). Sebelumnya sampel berwarna hijau, tetapi setelah diberi pelarut $\mathrm{NaOH}$ kemudian dikocok maka warna yang terbentuk pada sampel adalah warna kuning

\section{SARAN}

Dengan adanya penelitian ini kami berharap masyarakat atau pemerintah dapat mengetahui kadar flavonoid total yang ada pada tanaman daun melinjo (Gnetum gnemon L)

\section{DAFTAR PUSTAKA}

Aktivitas antioksidan senyawa flavonoid ekstrak etanol biji terong Belanda (Solanum betaceum, syn) dalam menghambat reaksi peroksidasi lemak pada plasma darah tikus Wistar. Cakra Kimia Indonesia-E Jurnal of Applied Chemistry. Volume 2
Fatchurrozak., Suranto., sugiyarto. 2013. Pengaruh ketinggian tempat dan Pendayagunaan Keanekaragaman Tumbuhan Lahan Kering. Bogor: Kebun Raya Bogor -LIPI. http://eprints.uns.ac.id/204/1/17049 22411201011351.pdf [17 Okt 2014]. terhadap kandungan vitamin C dan zat antioksidan pada buah Carica pubescens di dataran Tnggi Dieng. Pasca Sarjana UNS

Moniharapon, D, M. 2014. Ekstrak etanol daun melinjo (Gnetum gnemon L) Sebagai anti Feedant terhadap larva ulatgrayak (Spodoptera litura Fab.) pada tanaman sawi ( Brasica sinensis L.)

Mukhlisah, N, A. 2014. Pengaruh level ekstrak daun melinjo (Gnetum gnemonLinn) dan lama penyimpanan yang berbeda terhadap kualitas telur itik

Markham, K.R., 1988. Cara Mengidentifikasi Flavanoid, Diterjemahkan oleh Kokasih Padmawinata. Penerbit ITB. Bandung. Hanan, Abdul dan Sutrisno. 2000. Gnemon: Tumbuhan Lahan Kering Multi Guna dan Konservasinya di Kebun Raya Bogor. Seminar Nasional Konservasi Harborne, J.B. 1987. Metode fitokimia: Penuntun Praktikum.

Lestari,S. Muharfizah. 2015. Karakterisas fisikokimia kerupuk melinjo sebagai upaya diversifikasi produk olahan melinjo. [Skripsi online]. Fakultas 
pertanian, Universitas Hasanudin Makasar.

Nurnasari, E. Djumali. 2010. Pengaruh kondisi ketinggian tempat terhadap produksi dan mutu tembakau temanggung.

Parubak, A, S. 2013. Senyawa flavonoid yang bersifat antibakteri dari Akway (Drimys becariana.Glbbs). Universitas Negeri Papua.

Pinem, L, J. 2007. Perbedaan lingkungan dan masa tanam (Apium graveolus L.). Institut Pertanian Bogor.

Rahakbauw, I, D. 2016. Analisis senyawa flavonoid daun lamun Enhalus acoroides di perairan pantai Desa Waai Kabupaten Maluku Tengah. Universitas Pattimura. Ambon

Rais, R, I. 2015. Isolasi dan penentuan kadar flavonoid ekstrak etanolik herba Sambiloto (Andrographis paniculata (BURM. F NESS). Fakultas FarmasiUniversitas Ahmad Dahlan

Robinson, Trevor. 1995. Kandungan Organik Tumbuhan Tinggi. Penerbit ITB. Bandung.

Septiani, S., Wathoni, N., dan Mita, S.R. 2012. Formulasi Masker Gel Antioksidan dari Ekstrak Etanol Biji Melinjo (Gnetum gnemon Linn.). Skripsi. Fakultas Farmasi Universitas Padjajaran,Bandung.

Silalahi, J. 2006. Makanan Fungsional. Kanisius.Yogyakarta.

Sjahid, R, L. 2008. Isolasi dan identifikasi senyawa flavonoid dari daun Dewandaru (Eugenia uniflora L.).
Fakultas Farmasi, Universitas Muhamdiyah Surakarta.

Solichatun. Anggarwulan, E. Mudyantini, W.2005.Pengaruh ketersediaan air terhadap pertumbuhan dan kandungan bahan aktif saponin tanaman Ginseng Jawa (Talinumpaniculatum Gaertn.). Jurusan Biologi Universitas Sebelas Maret Surakarta.

Sunanto, H. 1993. Budi Daya Melinjo dan Usaha produksi emping. Kansius.

Takashi,M.,danTakayumi,S.1997.

Antioxidant Activities of Natural Compoud Found in Plants. JAgricFood Chem. 45 :1819-1822.

Voon, B.H., dan Kueh, H.S. 1999. The Nutritional Value of Indigenous Fruits and Vegetables in Sarawak.Asia PacJClin Nutr.8 (1) : 24-31.

Winarsi, Hery.2007. Antioksidan Alami dan Radikal Bebas. Kanisius. Yogyakarta. 